AperTO - Archivio Istituzionale Open Access dell'Università di Torino

Multi-method Analysis of Avian Eggs as Grave Goods: Revealing Symbolism in Conversion Period Burials at Kukruse, NE Estonia

This is a pre print version of the following article:

Original Citation:

Availability:

This version is available http://hdl.handle.net/2318/1626913

since 2017-06-20T12:05:39Z

Published version:

DOI:10.1080/14614103.2016.1263374

Terms of use:

Open Access

Anyone can freely access the full text of works made available as "Open Access". Works made available under a Creative Commons license can be used according to the terms and conditions of said license. Use of all other works requires consent of the right holder (author or publisher) if not exempted from copyright protection by the applicable law. 
This is the author's final version of the contribution published as:

Jonuks, Tõnno; Oras, Ester; Best, Julia; Demarchi, Beatrice; Mänd, Raivo; Presslee, Samantha; Vahur, Signe. Multi-method Analysis of Avian Eggs as Grave Goods: Revealing Symbolism in Conversion Period Burials at Kukruse, NE Estonia. ENVIRONMENTAL ARCHAEOLOGY. None pp: $1-14$.

DOI: $10.1080 / 14614103.2016 .1263374$

The publisher's version is available at:

https://www.tandfonline.com/doi/full/10.1080/14614103.2016.1263374

When citing, please refer to the published version.

Link to this full text:

http://hdl.handle.net/ 


\title{
Multi-method analysis of avian eggs as grave goods: revealing symbolism in Conversion period burials at Kukruse, NE Estonia
}

Jonuks, Tõnno, Estonian Literary Museum, Department of Folkloristics, Vanemuise 42, 51003, Tartu, Estonia, corresponding author, tonno@ folklore.ee

Oras, Ester, University of Tartu, Institute of Chemistry, Ravila 14A, 50411, Tartu, Estonia, ester.oras@ut.ee

Best, Julia, Department of Archaeology, Anthropology and Forensic Science, Faculty of Science and Technology, Bournemouth University, Poole, UK, BH12 5BB, bestj@ bournemouth.ac.uk

Demarchi, Beatrice, BioArCh, Department of Archaeology, University of York, York YO10 5DD, United Kingdom, beatrice@palaeo.eu

Mänd, Raivo, University of Tartu, Institute of Ecology and Earth Sciences, Department of Zoology, Vanemuise 46, 50411, Tartu, Estonia, raivo.mand @ut.ee

Presslee, Samantha, BioArCh, Department of Archaeology, University of York, York YO10 5DD, United Kingdom, slp534@ york.ac.uk

Vahur, Signe, University of Tartu, Institute of Chemistry, Ravila 14A, 50411, Tartu, Estonia, signe.vahur@ut.ee

\begin{abstract}
:
Eggshells are unusual finds in the Iron Age of eastern Europe (500 BC - 1200 AD) deserving extra attention in terms of analysis as well as interpretation. This paper discusses two rare eggshell finds, discovered in female burials at the conversion period $\left(12^{\text {th }}-13^{\text {th }}\right.$ century AD) cemetery at Kukruse, NE Estonia. Our multianalytical study combining FT-IR, SEM(-EDS), microscopy and ZooMS provides an overview of methods applicable for identifying egg species, their predepositional history and curation. Based on the analytical results and the comparative analysis of the content and context of these two burials, we argue that different aims and connotations lay behind depositing eggs as burial goods, allowing well-supported interpretations of both pagan and Christian religious worldviews simultaneously.
\end{abstract}

Keywords: eggshells, SEM-EDS, ZooMS, ATR-FT-IR, burial rituals, conversion, Christian vs pagan

\section{Acknowledgements}

This research was supported by the European Union through the European Regional Development Fund (Center of Excellence in Estonian Studies), by the Estonian Ministry of Education and Research (IUT 22-5), the Estonian Research Council postdoctoral project PUTJD64 "Feast in afterlife: Multidisciplinary study of ritual food in conversion period cemetery at Kukruse, NE-Estonia". Hatching profiling and additional microscopy was conducted at Bournemouth University as part of the AHRC funded "Cultural and Scientific Perceptions of Human-Chicken Interactions" project (Grant No AH/L006979/1), who Julia Best wishes to thank. Julia Best is also grateful to Mark Maltby and Mark Brisbane for their helpful comments on the manuscript. Beatrice Demarchi and Samantha Presslee are grateful to the Engineering and Physical Sciences Research Council (EPSRC; grant EP/I001514/1) and wish to thank Matthew J. Collins for useful discussion and support. The authors gratefully acknowledge the use of the Ultraflex III MALDI-TOF/TOF in the York Centre of Excellence in Mass Spectrometry, which was created thanks to a major capital investment through Science City York, supported by Yorkshire Forward with funds from the Northern Way Initiative. 


\section{Article}

\section{Introduction}

Eggshells are not common finds in the Eastern Baltic archaeological record, especially among prehistoric grave goods. This is partly due to poor preservation of the shells, and partly to the difficulty in distinguishing fragmentary and discoloured pieces from the surrounding soil during the excavation (Sidell 1993, 5). Indeed, until recently, eggshells were missing among prehistoric finds from Estonia, but this study shows that eggshell does survive (and may thus be more frequent than previously thought), but can be overlooked during fieldwork. This situation may however be different in urban excavations, where eggshells are common finds from Medieval cesspits, although until now this material has been largely left unstudied.

In 2009-2010 forty burials, from the end of the $12^{\text {th }}$ - beginning of the $13^{\text {th }}$ century, were studied during the rescue excavation at Kukruse, North-East Estonia (Lõhmus et al. 2011). The period coincides with the so-called Northern Crusades and the conversion period in the eastern Baltic. The cemetery provided a good overview of a society of the period. The majority of burials were accompanied by personal objects, such as brooches and metal parts of garments. In the eastern side of the cemetery a small cluster of four unusually rich females (burials no. I, VI, VII, XXII) and two males (no V, IX) were unearthed. This cluster of wealthy burials formed a distinct group, where all burials were arranged with the heads towards the West, whereas across the rest of the cemetery other orientations were also used. Eggshell fragments representing a whole egg were found in two female burials - VI and VII - and a smaller amount of eggshell was found during laboratory work from burials I and XXII.

Being unusual finds in Estonian Iron Age and Early Medieval burials, we conducted an indepth analysis of the two eggs from burials VI and VII. This article introduces the multianalytical approach employed to identify these eggs to species, and explores their treatment before and within the burials. Combining these results with contextually and temporally comparable material the paper then discusses the variable meanings of, and reasons for, including eggs as grave goods.

\section{Context: Burials VI and VII at Kukruse}

Burials VI (Fig. 1) and VII (Fig. 2), probably originally encased in wooden coffins, were located sideby-side, one metre apart. Both contained elderly (50+ years) female inhumations. The sex of the burials was determined by Martin Malve (University of Tartu) according to the morphological traits on the pelvis and cranium (Buikstra \& Ubelaker 1994, 16-20) and the maximum length of the long bones (Garmus \& Jankauskas 1993, 6-8). The age at death was determined according to the changes in pubic symphyseal face (Todd 1921, 1-70), wearing of the teeth (Brothwell 1981, 72) and agecaused changes on the limb joints (Ubelaker 1989, 84-87). Pathological conditions were identified with the aid of Ortner \& Putschar (1985) and Roberts \& Manchester (2012). Both inhumations had a rich selection of ornaments - bracelets, impressive breast chains, necklaces, decorated belts and knife sheaths etc. At the foot of both individuals was a rich selection of tools - scythes, knives, needles, and a ceramic vessel originally filled with food. A large cross pendant, hanging from the breast chain of burial VI, and prominent silver pendants with cross symbols in the necklaces of both females suggest a Christian worldview. Other symbolic objects like a horse-shaped pendant on the shoulder and several other pendants with various symbols (including pentagrams) were present in inhumation VII. The silver pendants found in burial VI also represented various symbols.

The eggshell within inhumation VII was found between the female's femora, lying on top of the lower extremity of the large breast chain ornament. The egg was placed on top of her clothing and 
ornaments and was thus clearly visible to mourners. The pieces of eggshell laid in a limited area, c. $5.5 \times 3.2 \mathrm{~cm}$, indicating that the egg was intact at the time of burial. Despite the fragmentation some larger pieces were evident at the time of excavation. The eggshell fragments were a dirty-beige colour, and some of them bore spots of red paint (Fig. 2 B).

The egg in inhumation burial VI was found in a different location of the grave - set at the foot, between a ceramic vessel and the toe-bones of the deceased. The vessel was in very poor condition with different parts of the pot being mixed and moved to some extent by various post-depositional processes. This unclear stratigraphy means that it is difficult to estimate the exact placement of the egg. The eggshell fragments lay just underneath the sherds from the shoulder and neck area of the pot (their outer surfaces facing upwards) without any separating layer of soil. Since there do not seem to be any sherds under the eggshells, it is more likely that the egg was initially placed just next to the pot. Later, the brittle pot collapsed under the pressure of soil and the sherds from the upper part of the vessel shifted on top of the egg.

\section{The bird species: microscopic analysis and ZooMS}

To determine the species of bird that the eggs came from, several different methodologies were employed. To provide a preliminary assessment the approximate sizes of the eggs were compared with those of modern bird species, reported in the scientific literature (e.g. Makatsch 1974, 1976; Keepax 1981). The egg from burial VII measured c. $5.5 \times 3.2 \mathrm{~cm}$ and the one in burial VI measured c. $6 \times 5 \mathrm{~cm}$. These dimensions are approximate, as the contours of the eggs were not preserved in the soil. Eggs can become deformed in the soil before or during the excavation, and even within one species (particularly domestic birds) egg size can be very varied, making this technique only useful for initial taxonomic assessment.

The egg from the VII burial was analysed by two different visual methods. Firstly, the density of mammillae was measured by microscopy following Sidell (1993) and Bušs \& Keišs (2009). Specimens were examined using a Keyence Digital Microscope VHX 5000 series and photographs were taken. The density of mammillae was calculated by counting every whole mammilla on the screen within a fixed area. Parts of mammillae at the edge were not counted. These counts were converted to an average per square millimetre (Sidell 1993).

Secondly, the eggshell thickness was measured using multiple fragments and areas of the shell to form a mean thickness calculation (Fig. 3). Approximate measurements were also taken from the egg in burial VI (Fig. 4). The obtained data were compared with the corresponding data of different avian species provided by Sidell (1993) Keepax (1981) and Romanoff and Romanoff (1949). It has to be taken into consideration that the preservation of eggshells may have been adversely affected by soil conditions. However, the soil in northeast Estonia has mainly basic characteristics, due to the limestone bedrock, and as such any destructive influence of the soil's $\mathrm{pH}$ was unlikely to have been very significant, but could have resulted in some recrystallization and precipitation of $\mathrm{CaCO}_{3}$.

Comparing the thickness measurements of the egg from burial VII with those from eggs of species in modern Estonia, most bird species could be excluded, including all small passerines, geese, and swans. However, several species of Laridae, Anatidae, Falconiformes, Charadriiformes, Galliformes and Corvidae have similar measurements to the archaeological examples from Kukruse. As domestic chicken was a likely candidate, eggs from multiple breeds were compared. Today there is great variation within the eggs of some domestic species, including chickens, and as such this is a factor that must be considered when using modern reference material. The thickness measurements were considerably smaller than those of some eggs of modern commercial domestic chickens, but similar to, and larger than, other breeds such as the leghorn. The egg from burial VI had a smaller average thickness (of c. $0.26 \mathrm{~mm}$ ) than the egg from burial VII.

The density of mammillae per $\mathrm{mm}^{2}$ was also compared with counts from modern reference species (Fig. 5). By combining the data from both of these microscopy techniques, five species were identified, in which the values of both parameters overlapped with those of the egg from the Kukruse 
VII burial: domestic chicken, cormorant, common gull, lesser black-backed gull, black guillemot and turkey. As turkey was only introduced in Europe in the $16^{\text {th }}$ century (Smith 2006; Beacham \& Durand 2007) it can be discounted. With the exception of chickens (see below) the history of the other species in Estonia is poorly understood, but they were all likely to have been present in the $12^{\text {th }}-13^{\text {th }}$ century. Thus, although chicken was a very likely candidate, the other species could not be dismissed on the basis of these parameters alone. Unfortunately, the mammillae were too damaged to allow further morphological studies, which can provide taxa-specific characteristics (see below). As such, more conclusive species identification was needed.

ZooMS (Zooarchaeology by Mass Spectrometry) was therefore carried out on eggshell fragments from both burials (VI and VII) to identify the eggshell taxa, based on their biomolecular signature (Stewart et al. 2013; Presslee 2015). In brief, an eggshell fragment from each burial was selected, photographed and cleaned with $1 \mathrm{ml}$ 0.5M EDTA (ethylenediaminetetraacetic acid) for 1520 minutes and then sonicated for 3 minutes to remove any adhering sediment. The eggshells were then rinsed in ultra-pure water, dried, crushed (ca. $<500 \mu \mathrm{m}$ in size) and exposed to bleach for 100 hours to isolate the intra-crystalline fraction of proteins (Penkman et al. 2008; Demarchi et al. 2011; Stewart et al. 2013; Demarchi et al. 2016). During the processing of the samples, it was noted that eggshell from burial VII was more degraded, with a black residue being seen during bleaching, raising the possibility that this eggshell was burnt.

After 100 hours the powders were rinsed five times with ultrapure water, briefly suspended in HPLC-grade methanol in order to remove any residual bleach, and then air-dried. Once dry the samples were fully demineralised in cold $0.6 \mathrm{M}$ hydrochloric acid, neutralised, freeze-dried and the liophilisate re-suspended in $200 \mu 150 \mathrm{mM}$ ammonium bicarbonate. Reduction and alkylation were carried out using $1 \mathrm{M}$ DL dithiotheritol (DTT) and $0.5 \mathrm{M}$ iodoacetamide (IAA) and digestion was performed overnight in a heating block set at $37^{\circ} \mathrm{C}$ using $4 \mu 1$ of $0.5 \mu \mathrm{g} / \mu \mathrm{l}$ porcine trypsin.

Conventional zip-tipping (e.g. van Doorn et al. 2011) then purified the digests and $1 \mu 1$ of eluate was spotted in triplicate onto a MTP384 Bruker ground steel MALDI target plate. $1 \mu 1$ of $\alpha$ cyano- 4-hydroxycinnamic acid matrix solution ( $1 \%$ in $50 \%$ ACN/ $0.1 \%$ TFA (v/v/v)) was added to each sample spot and mixed with the sample. The samples were left to air-dry on the plate ready to be analysed on a Bruker Ultraflex MALDI-ToF (matrix-assisted laser desorption/ionisation time of flight) mass spectrometer.

Samples were analysed using the following parameter settings: ion source $25 \mathrm{kV}$, lens voltage $9 \mathrm{kV}$, laser intensity 40-55\%, and mass range 800-4000 Da. The mass spectra were externally calibrated against an adjacent spot containing 6 peptides (des-Arg ${ }^{1}$ Bradykinn $m / z=904.681$, Angiotensin I $m / z=1295.685$, Glu ${ }^{1}$-Fibrinopeptide B $m / z=1750.677$, ACTH (1-17 clip) $m / z=2093.086$, ACTH (18-39 clip) $m / z=2465.198$ and ACTH $(7-38$ clip) $m / z=3657.929)$.

The resulting mass spectra were analysed using mMass (Strohalm et al., 2010), an open-source mass spectrometry tool. All spectra were cropped to between $800-3000 \mathrm{~m} / \mathrm{z}$ and all peaks with a signal-to-noise ratio of 9 or above were identified as genuine peaks, i.e. representing a peptide. The three replicates for each sample were averaged and this averaged spectrum was compared (within a tolerance of $0.1 \mathrm{Da}$ ) to an eggshell peptide mass reference collection (Presslee 2015). Both Kukruse samples produced good quality spectra and when compared to the reference peptides an identification of Gallus gallus could be concluded for both samples, with 7 peptide markers specific for G. gallus being identified in both (Fig 6). The excellent preservation of the proteins seems to exclude any significant heating/burning of the specimens.

\section{ATR FT-IR and SEM-EDS analysis: painted eggshell from burial VII}

\section{Red painting on egg from burial VII}

The red spots of colour, observed on the outer surface of the eggshell in burial VII, were identified as paint (Fig. 2B). The chemical composition of this red paint was analysed using attenuated total reflectance (ATR) Fourier' transform infrared spectroscopy (ATR-FT-IR spectroscopy) and 
scanning electron microscopy with energy-dispersive X-ray spectroscopy (SEM-EDS).

ATR-FT-IR spectroscopy is a minimally destructive technique, which allows the analysis of very small samples of both organic and inorganic materials (Vahur et al. 2009; 2010). The ATR-FTIR spectrum was acquired on a Nicolet 6700 FT-IR spectrometer with a "Smart Orbit" diamond micro-ATR accessory. The spectrometer has DLaTGS Detector, Vectra Aluminum Interferometer and sealed and desiccated optical bench with CsI optics. Samples were taken from the eggshell under a light microscope with a scalpel, placed directly on the ATR crystal, then pressure was applied and the ATR-FT-IR spectrum was acquired. The following spectrometer parameters were used: resolution 4 $\mathrm{cm}^{-1}$, spectral range $225-4000 \mathrm{~cm}^{-1}$, number of scans: 256, Level of Zero filling: 0, Apodization: Happ-Genzel. Thermo Electron's OMNIC software 7.3 for FT-IR spectrometer was used to collect and process IR spectra.

The paint on the eggshell was also analysed with SEM-EDS. Analyses were conducted using a variable pressure Zeiss Evo15MA scanning electron microscope (SEM), equipped with an Oxford $\mathrm{X}$-MAX energy dispersive detector system (EDS). Measurements were performed without prior calibration and therefore the obtained EDS spectrum yields only qualitative information. The sample was uncoated (but fixed onto a sticky carbon conductive tab) and studied in variable pressure mode using $20 \mathrm{keV}$ accelerating voltage and focused electron beam. The EDS spectrum was afterwards processed using the Aztec software.

The ATR-FT-IR and EDS spectra of the red paint sample are presented in Figs. 7 and 8. The results obtained with ATR-FT-IR were confirmed by independent SEM-EDS analysis.

The ATR-FT-IR spectrum of red paint suggests the presence of red ochre $\left(\mathrm{Fe}_{2} \mathrm{O}_{3}+\right.$ $\left.\mathrm{Al}_{2} \mathrm{O}_{3} \cdot 2 \mathrm{SiO}_{2} \cdot 2 \mathrm{H}_{2} \mathrm{O}\right)$ and calcite $\left(\mathrm{CaCO}_{3}\right)$. In the ATR-FT-IR spectrum it is possible to identify absorption bands that belong to kaolinite $\left(3695 \mathrm{~cm}^{-1}, 3619 \mathrm{~cm}^{-1}, 1000 \mathrm{~cm}^{-1}, 914 \mathrm{~cm}^{-1}, 799 \mathrm{~cm}^{-1}, 780\right.$ $\left.\mathrm{cm}^{-1}, 695 \mathrm{~cm}^{-1}\right)$ and calcite $\left(1797 \mathrm{~cm}^{-1}, 1407 \mathrm{~cm}^{-1}, 871 \mathrm{~cm}^{-1}, 711 \mathrm{~cm}^{-1}\right.$ ) (Vahur et al. 2016). Iron(III)oxide (hematite), as the main pigment component, has Fe-O absorption bands in the far-IR region in the range of 560-225 $\mathrm{cm}^{-1}$ (Vahur et al. 2009, Marshall et al. 2005, Kustova et al. 1992). However in the far-IR region kaolinite has also additional absorption bands in the same area as the $\mathrm{Fe}-\mathrm{O}$ absorption bands; in the IR spectrum of the red sample probably the kaolinite and iron oxide $(\mathrm{Fe}-\mathrm{O})$ bands are overlapping. In the EDS spectrum the elements $\mathrm{Fe}, \mathrm{O}, \mathrm{Si}, \mathrm{Al}$ are identifiable, which all are in the composition of the red earth pigment (or red ochre). Other elements (e.g. $\mathrm{Cu}$ ) in the EDS spectrum are in the composition of the additives that can be found on the eggshell or in the sediments attached to the shell. The organic binding medium was not identified, probably because it was highly degraded.

In conclusion, the ATR-FT-IR and SEM-EDS spectra both indicate that the red paint sample consist of red ochre and calcite as the two main components. The calcite component may originate from the paint as a filler material, or from the eggshell itself.

\section{Hatching and burning: analysis via high-powered digital microscopy}

Three fragments were selected from both eggs for detailed analysis using a Keyence Digital Microscope VHX 5000 series. Examining the morphological characteristics of the eggshell under high magnification can be useful for species assignment (although there are limitations to this technique) but its application to archaeological eggshell is particularly valuable for determining the developmental state of the eggs (Best et al. in prepB; Beacham and Durand 2007, 1610-1615; Sidell 1993). The reabsorption of calcium from the eggshell by the developing chick changes the visual appearance of the internal surface of the eggshell.

The eggs from both of the Kukruse burials showed regular reabsorption, a feature which is primarily associated with chick development (Fig. 9). This therefore indicates that the eggs were fertilised and would have contained a developing chick. The eggshell from burial VI displayed reabsorption characteristic of being late in the incubation sequence, close to the point of hatch. As such this egg would have been incubated by the hen before it was selected for deposition in the grave environment. The eggshell from burial VII was at least halfway through the development sequence, but had been incubated for less time than the specimen in burial VI. The use of fertilised and incubated 
eggs in both of the graves may be coincidental, resulting from the selection of eggs with an unknown level of development. However, it is also plausible that developing eggs were selected intentionally. An egg early in its incubation sequence may have been taken without knowing the state of development, but the longer the egg is incubated the more identifiable the presence of the chick within becomes. The hatching profiles thus indicate that the eggs had been incubated for approximately $12-$ 20 days before being selected for burial (Best et al. in prepA; Beacham and Durand 2007; Blom and Lilja 2004; Karlsson and Lilja 2008). No direct evidence of burning was seen under the microscope. Although this does not negate the possibility that these eggs have been heated, since temperature does not always alter the eggshell structure visually, it is also consistent with the excellent observed protein preservation of the eggshell, eliminating any significant heating.

\section{Discussion}

\section{Chicken, eggshells and artificial eggs in the $11^{\text {th }}-13^{\text {th }}$ century AD Eastern Baltic}

The earliest examples of domestic chicken in Estonia are dated to the $2^{\text {nd }}-1^{\text {st }}$ century $\mathrm{BC}$, as bones were found in a Tõugu II stone grave (Maldre 2000, 412; Lang 2000, 124) (Fig. 10). These bones came from the stone layers from the infill of the grave but also from its surroundings and thus may belong to later periods. However, the presence of chicken bones in the lower layers of grave infill suggests that bones could have been deposited there during the construction of the grave. Until the samples are directly dated such an early date for chicken presence in Estonian archaeological contexts remains unproven. In the Iron Age contexts chicken bones are present in different sites, although usually only in small numbers, especially in comparison to other domestic animals (cattle, sheep/goat, pig). From several Iron Age graves unspecified bird bones have been reported, e.g. Maidla II (Maldre 2003, 273) and Lahepera (Lavi 1980, 367), which could be chicken bones. More numerous finds, of both chicken bones and eggshells, occur in the Medieval urban and castle contexts, especially from cesspits, from the $13^{\text {th }}$ century AD onwards (Rannamäe \& Lõugas, in press). In the neighbouring area of north-west Russia, chickens were relatively well represented in the $9^{\text {th }} / 10^{\text {th }}$ century fortified settlement of Ryurik Gorodishche, and in the earliest levels (10th/early 12th century) of the nearby town of Novgorod, where from the mid $12^{\text {th }}$ century they become the most common bird species (Maltby 2012, 369-371).

Some finds from the Late Iron Age $\left(9^{\text {th }}-13^{\text {th }}\right.$ century AD) also indicate that possible symbolic meanings were associated with the chicken. Three carpometacarpus bones were discovered from Lõhavere hillfort, which had once been hung on a bronze chain, as evidenced by the preserved bronze ring. Additionally a pierced tarsometatarsus with a spur (and thus probably from a male individual) was found at Otepää hillfort (Jonuks \& Rannamäe in press). Thus, the chicken could have been present in Estonia from the pre-Roman Iron Age, although in small numbers, gained some symbolical value during the Late Iron Age, and became common from the $13^{\text {th }}$ century AD onwards.

Though rare in Estonia, eggshells occur quite often at the Late Iron Age, $10^{\text {th }}-13^{\text {th }}$ century AD cemeteries at the lower reaches of River Daugava, Latvia. For instance, at the Lejasžagaris cemetery a male inhumation was found: the individual had probably been buried around 1000 AD together with a richly decorated sword, spearheads, numerous jewellery items and scales. At his head were a ceramic vessel, a drinking horn and eggshells (Urtāns 1973, 70). Fragments of eggshells have also been found among the grave goods of a juvenile burial (no. 382) at Laukskola cemetery (Zarina 1973; 2006) and from several graves in the Vampenieš cemetery, on Dole Island (Urtāns et al. 1969, 282).

Besides natural eggs several examples of ceramic eggs have been found, e.g. from the same period cemeteries of Lipši (Daiga 1976) and Salaspils Laukskola (Zariņa 2006, 274) at the lower reaches of the River Daugava; Latvia. Fragments of artificial eggshells, glazed with black and yellow decoration are also known from Gotland and Sigtuna, where these are associated with Slavic tradition (Sohlman 2004, 8; Stenberger 1977, 472). Artificial eggs have been found in inhumation burials in Poland, mostly from female burials (Shephard 2008, 145). Such ceramic eggs are hollow inside and contain a small ball, which can make sound and can be used as a rattle. 
Besides burial contexts, ceramic eggs, covered with red, yellow and black decoration are known from urban centres across Northern Europe, including, amongst others, two fragments from Tartu, Estonia (Tvauri 2001, 162). Most numerously ceramic eggs have been reported from Russia, where Kiev has usually been considered to be the area of production for these items. Near to Estonia ceramic eggs and fragments of these were found from Medieval Novgorod and its northern hinterland (e.g. at Minino in Byeloozero) (Kolchin 1985, 133; Makarov 2012, 54). The ceramic eggs from Minino were found in burials and are well dated to the $11^{\text {th }} / 12^{\text {th }}$ century. The oldest examples of such eggs belong to the $11^{\text {th }}$ century and their main period of use appears to be the $12^{\text {th }}-13^{\text {th }}$ century (Stenberger 1977, 472; Lõugas 1981; Shephard 2008). Such examples of artificial glazed eggs could share similar uses and meanings to the red-painted egg from the burial VII at Kukruse. Possible connotations of Eastern Christianity are also evident in other archaeological remains, but additionally through linguistics (see below).

\section{Interpretation: eggshells as gravegoods at Kurkuse cemetery}

The deposition contexts of eggs in the Kukruse cemetery and the diverse usage of eggs for symbolical reasons across northern Europe and Russia during the $11^{\text {th }}-13^{\text {th }}$ century AD is suggestive of different purposes and meanings being ascribed to eggs. The broadest frame, in which the meaning of eggs has been discussed, is in terms of the dichotomies between pagan/Christian and between symbolic/utilitarian. Often treated as oppositional concepts, we suggest that such seemingly opposed ideas could well be used simultaneously by the same group and thus it is only the context of each individual egg deposit which will reveal its meaning. Instead of the common notion to use concepts of syncretistic or hybrid religion, which would also be relevant in the context of Kukruse cemetery, the more direct and qualitative concepts of Christian and pagan are preferred in this text. As it will be shown below, the clearly exhibited Christian symbolism could have been crucial for religious identity of at least part of this society. Thus the concept of syncretistic or hybrid religion (see Andrén et al 2006, 14), even though being a more inclusive and less extrapolated academic approach, may not be the most appropriate in discussing this society. By using these opposite concepts we do not intend to suggest that such traditionally opposing religions existed. Rather the broader intention is to study the relationships of different religious identities during the Conversation period on the emic level.

The context of the egg from inhumation VII suggests that complex religious meanings prevailed in this case. Painted in red, placed between thighs, on top of clothing and breast-chains, it was prominently displayed and thus it is unlikely to represent an ordinary food-deposit. The usual location of food deposits was at the head or foot of the inhumations, as indicated by ceramic vessels in other burials or a fish placed beside the foot of burial XLIII in the same cemetery. The religious meaning is further highlighted by the use of red paint, which appears to imitate the artificial ceramic eggs. The painted example from Kukruse is so far the only natural painted egg from this region.

The religious meaning of an egg as a grave good can have two contradictory interpretations either related to pagan cosmogony or Christian symbolism. Within the traditional pagan discourse the egg between thighs of a female burial could first be associated with female fertility (Valk 2000, 148) and the selection of eggs that are relatively late in their incubation sequence may give credence to this interpretation. However, within the wider tradition, eggs have also been deposited in male graves, and as such this interpretation seems not to be plausible in all examples but could be a factor in individual contexts. In addition, both examples from Kukruse are associated with elderly females, beyond child-bearing age.

Another pagan interpretation associates eggs with a creation myth, where the universe originated from a bird's egg (Napolskihh 1989) and could thus be used as a symbol of the world and its cyclical rebirth. Examples of such a creation myth can be found in Estonian folklore (Eisen 1927, 6ff), and also from the Kalevala, the most famous epic of Baltic-Finnic tribes. According to the myth, a bird was flying above the primeval ocean (or in some versions also above grasslands) and was looking for the place for a nest. The bird laid an egg or eggs, which gave rise to the rest of the world. However, it is not known whether such a bird or its eggs have been used in rituals and in actual 
worship. Representing the classic deus otiosus phenomenon, a deity who has been active in the creation of the universe but not guarding over it afterwards, such a creature usually does not become an object of worship. The interpretation based on creation myth and female fertility also relates to a much broader time-span than only the Late Iron Age, from where all Eastern Baltic egg-finds come. Those aspects make the connection between the Kukruse eggs and the universal creation-myth contextually vague and unlikely to be the primary interpretation of the Kukruse specimens.

Within the Christian tradition, the broadest symbolism associated with eggs is the manifestation of the resurrection of a soul, which was one of the most fundamental elements in Early Medieval Christianity (Paxton 2008, 383). The idea is represented by painted eggs, which symbolize the resurrection of Jesus Christ. According to Christian tradition, an eggshell symbolises the tomb of Jesus where a new life comes forth and thus the egg symbolises the resurrection of the Son of God. The red paint on the eggs symbolizes the blood of Jesus and his sacrifice for mankind. It is interesting to note that according to this theological approach, the egg that symbolises resurrection has to be hatched, as no new life comes out of unfertilized eggs, similarly nobody can rise from the dead without God's participation (Chafer 1976, 91). This idea makes a strong connection with the late development stage of the eggs proposed in this study, but the existence of such deep theological thoughts in a pagan or recently-converted society is still doubtful.

However, the use of an egg as a representation of new life is such a universal symbol that it cannot be excluded from pagan traditions. Jonathan Shepard $(2008,145)$ has suggested that similar symbolic meanings could have been present behind the deposition of eggs in Christian and nonChristian societies, associated with fertility and resurrection of soul. Thus it is possible that in earlyChristian or pagan-Christian northern Europe the egg was a symbol of resurrection which could also symbolise the new life of the deceased and as such be suitable to both worldviews.

The dating of the egg-finds seems to be crucial here, as all deposits of eggs interpreted as symbolic have been found from the $11^{\text {th }}-13^{\text {th }}$ centuries AD. This period marks the spread of Christianity over northern Europe, and elements of Christian religion are clearly evident in Estonian religion at that time (for more detail Jonuks \& Kurisoo 2013). Vello Lõugas (1981) has also associated the deposition of eggs in graves in the lower reach of the River Daugava as a marker of Christianity. The new faith was important in Eastern Baltic, especially as several trading routes passed the mouth of the River Daugava and thus the Christian religion from both Russia (officially Christianised at the end of the $10^{\text {th }}$ century) and Scandinavia (Christianised $10^{\text {th }}-11^{\text {th }}$ century) had a major impact on communities there. It is likely that the earliest Christian elements spread to the eastern Baltic from Russia (Selart 2009, 274). Linguistic evidence, like loan words rist (cross), papp (priest), raamat, (book, also Bible in Finnish) from Russian are used to argue this (Loorits 1962, 11). Furthermore several exclusive Christian ornaments, like the encolpion from Viltina, Saaremaa Island, and two round pendants carrying the image of Christ Pantocrator from the $12^{\text {th }}$ century East Estonia suggest the major role of Eastern Orthodox Church in introducing Christianity to Eastern Baltic (see also Jonuks \& Kurisoo 2013). The tradition of depositing eggs into graves, especially those painted in red, known widely in the eastern area of Europe throughout the Early Medieval period, only confirms this orientation (Eckstein 1987, 615). Therefore the location of the egg in burial VII, its clear curation prior to burial (painted red), and the Christian iconography displayed in the necklace of this wealthy female, make the Christianity-related connotation of this symbolic item the most plausible explanation.

The egg in burial VI appears to tell a different story, but the picture is complex again. The egg is separated from the clothing and jewellery, and instead deposited together with 'utilitarian' burial goods, like the tools, at the foot of the deceased. Furthermore, the egg was found adjacent to a ceramic vessel, which very likely served as a vessel for containing food, perhaps meant to be consumed by the deceased in the afterlife. Therefore in this instance a food-related ritual connotation is more apparent. Although the egg does not show any specific contemporary curation like painting, it must have been placed in the burial as a separate and clearly visible item, perhaps in a demonstrative, act: being white and fragile it may have been a focus point for the audience and for the person placing it next to a decorated pot in the coffin. It is therefore likely that the function and meaning of the egg in 
this burial is less religiously symbolic, but rather related to food consumption, though in that case in the afterlife. This makes the egg from the burial VI a potential example of a food offering, probably primarily relating to the concept of afterlife, where life continues similarly to that which has already been lived. This example could be compared with the cremation burials from Björkö, where eggshells were found among other waste of food, and with other examples such as the male burial from Lejasžagaris etc. (Stenberger 1977, 472; Urtāns 1973; Samdal 2000, 97). Considering the deposition context, the egg in burial VI could therefore be interpreted as a food offering. However, the indicated very late incubation point of the egg in grave VI complicates this interpretation. Whilst eggs with chicks inside them can be considered a culinary delicacy, the selection of a well-incubated egg for deposition in the grave may suggest that the egg grave-good was at once both a symbolic representation of a food product, but also a symbol of rebirth and activity in the afterlife.

\section{Pagan and Christian Eggs?}

The role of eggs in both graves must be considered as part of the wider pattern of grave goods in the cemetery. Besides the symbolic meaning of either the food for the afterlife or a symbol of resurrection, these meanings become significant only in wider ideological and religious contexts. The exhibition, which seems to have been important for both burials, the scarcity of eggs in the rest of the cemetery, the location of these two burials within the cemetery, as well as other burial goods inhumed with the two elderly females must be considered. The two wealthy female burials with eggs in their graves were located to the eastern part of the burial ground surrounded by other richly furnished graves. This overall pattern suggests certain intentional separation and status-based burial locations within the cemetery and community, indicating that the women with eggs belonged to the higher strata of society.

Although symbolic objects were rare in Kukruse cemetery, these were concentrated on wealthy burials and carried predominantly Christian symbolism. Inhumation VII had a silver round pendant with a cross sign in the central position of its necklace. Inhumation VI was adorned with another silver pendant with cross sign in the necklace and a second massive cross pendant hanging from her breast chain (Fig. 11). In addition to these two, another wealthy female (burial I) in this part of a cemetery was also accompanied with silver pendants carrying crosses. The fact that only wealthy females have Christian symbols in their burial paraphernalia might indicate that these members of society were more open to, and also willing to display, negotiations between the old pagan and new Christian traditions.

It is plausible that it was the nobility that were more active in foreign contacts (trade, intermarriages, chiefly connections and networks etc.) and thus more influenced by new traditions and different cultural manifestations, including the acceptance of Christian burial customs and display of its symbols. Such customs and symbols could not function as isolated phenomena and were introduced to the already existing religion and worldview. Other grave goods, such as tools and ceramic vessels containing food, suggest that pure Christianity was not the only identity active in the lives and deaths of these people. Elements relating to the ideas of resurrection of the soul and securing life after death can be associated with the concepts of afterlife in both worldviews. This mixture of indicators of different religions suggests that the elements of a foreign and prestigious religion were incorporated into the traditional worldview, especially in the wealthier part of the society (Mägi 2002, 109; Jonuks \& Kursioo 2013).

The mixing and matching of different religions indicating certain hybridization of worldviews is also supported by the proposed different meanings and functions of the eggs, even within the Kukruse cemetery. For burial VII the red-painted egg was placed on top of all clothing and decoration on the lap of the female and is more likely to be a symbol of Christianity or other mixed religious attributes. For burial VI, the egg is more indicative of a symbolic food offering, making it more pagan in its associations. Thus, the same object - a chicken egg - can reflect symbolism from different religious worldviews, particularly in contexts where both of the females simultaneously have indications of Christianity (symbols on pendants) and paganism (overall selection of burial goods). Thus, these two unusual egg finds from Kukruse serve as an excellent example of the overall religious 
nature in the conversion period of eastern Baltic societies, where different religions, traditions and concepts of afterlife were mixed and acculturated simultaneously. It is therefore inappropriate to look for one single religious assignment or symbolic association - either Christian or pagan - and instead they should be seen as part of the wider concept of a pagan-Christian mortuary practice (Jonuks \& Kurisoo 2013).

\section{Conclusion}

Studying eggshells from the $12^{\text {th }}-13^{\text {th }}$ century Kukruse cemetery exemplifies the importance of (as well as difficulties in) identifying and interpreting this fragile find type. The actual number of eggs found in inhumation cemeteries in the eastern Baltic could well be higher, but it can be challenging to recover fragmentary eggshells from the local moraine topsoil. As a result of the multiple scientific analyses carried out on the two eggs discovered in situ from burials VI and VII at Kukruse we can confirm that these eggs belonged to chicken. The two eggs demonstrate different meanings may have been ascribed to these eggs. The red-painted egg on top of the clothing and adornments of the wealthy female in burial VII most probably had a symbolic meaning, which, considering the wider religious context at that time in eastern Baltic, was associated with Christianity. The painted egg was an important symbol in Early-Medieval Christianity, representing the tomb of Jesus where the new life started, but also the resurrection and eternity of the soul. The latter association, which was probably one of the first Christian concepts to be incorporated into local traditions about the afterlife, was likely the reason why the egg was deposited into the grave.

The other egg, found at the foot of a female burial VI, together with other grave-goods, such as scissors, knives and a pot, which was probably filled with food, is therefore more likely to be associated with food deposits for the deceased. However, as the eggs in both cases appear to have been fertilised and development of the chick was in its later stages, additional symbolic interpretations could be speculated.

The two additional eggs from burials I and XXII discovered are also from wealthier graves. As the ornaments in those burials also included references to Christianity (cross pendant and silver pendants with cross-signs), it can be concluded that by the end of the $12^{\text {th }}$ century, but before the official Christianisation of Estonia at the beginning of the $13^{\text {th }}$ century, Christian elements and concepts were familiar to Estonian Late Iron Age people and associated mostly with the nobility. However, at the same time the other grave goods indicate that the concept of afterlife of this social group was far from only Christian. Being not purely Christian, but not entirely pagan either, the community represented at Kukruse could be interpreted as an example of a local declination of pagan Christianity. 


\section{Figures}

Fig. 1 Burial VI from Kukruse cemetery (A). The location of the egg is marked by the red circle and a close-up of eggshells under the potsherds (B).

Fig. 2 Burial VII from Kukruse cemetery. The location of the egg on top of decorative objects between the femora is marked by the red circle (A). A close-up of an eggshell fragment with partially preserved red paint (B).

Fig. 3 Comparison of the mean eggshell thickness of the Kukruse VII eggshell (encircled) with some other candidate bird species (data for wild bird species obtained from Sidell [1993]; data for some chicken breeds taken from Keepax [1981] and Romanoff and Romanoff [1949]). The light blue rectangles show species whose corresponding values overlapped with those of the Kukruse egg. Whiskers denote minimum and maximum values.Eggshell thickness measurement for Kukruse VI specimen.

Fig. 4 Eggshell thickness measurement for one Kukruse VI specimen.

Fig. 5 Comparison of mean density of mammillae per $\mathrm{mm}^{2}$ in the Kukruse VII eggshell (yellow column) and in some other candidate bird species (data obtained from Sidell 1993). Yellow lines show species whose corresponding values overlapped with those of the Kukruse egg. Whiskers denote minimum and maximum values.

Fig. 6 The average spectra (obtained on 3 analytical replicates) of the Kukruse eggshell from burials VI and VII. Both spectra show multiple markers fot G. gallus.

Fig. 7 ATR-FT-IR spectrum of red paint on the eggshell from burial VII

Fig. 8 EDS spectrum of red paint on the eggshell from burial VII.

Fig. 9 Internal surface of eggshell from burial VI (A) showing extensive reabsorbtion, and internal surface and internal surface of eggshell from burial VII (B) showing moderate reabsorbtion.

Fig. 10 Sites with egg finds from Estonia and Latvia mentioned in the text. 1 - Kukruse, 2 - Tõugu, 3 - Maidla, 4 - Lahepera, 5 - Lõhavere, 6 - Otepää, 7 - Tartu, 8 - Lejasžagaris, 9 - Laukskola, 10 Vampenieš, 11 - Lipši.

Fig. 11 Silver pendants from inhumations VI and VII. 
Bibliography 
Andrén, A. Jennbert, K. Raudvere, C. 2006. Old Norse religion. Some problems and prospects. In: Andrén, A., Jennbert, K., Raudvere, C. (eds.) Old Norse religion in long-term perspectives. Origins, changes, and interactions. Vägar till Midgård, 8. Nordic Academic press, 1114.

Beacham E.B. \& Durand S.R. 2007. Eggshell and the archaeological record: new insights into turkey husbandry in the American Southwest. Journal of Archaeological Science, 34: 16101621.

Best, J., Maltby, M., Demarchi, B. In prepA. Counting chickens before they hatch: developing identification of embryonic stage in eggshell for archaeological application.

Best, J., Demarchi, B., Presslee, S., Collins, M., Maltby. M. In prepB. Integrated application of ZooMS and microscopy in the study of archaeological eggshell.

Blom, J., Lilja, C. 2004. A comparative study of growth, skeletal development and eggshell composition in some species of birds. Journal of Zoology, 262, 361-369.

Brothwell, D. R. 1981. Digging up Bones. New York.

Buikstra, J. E. \& Ubelaker, D. H. (eds.). 1994. Standards for Data Collection from Human Skeletal Remains. Arkansas Archeological Survey Research Series, no. 44. Arkansas.

Bušs A., Keišs O. 2009. Method for identification of avian species by eggshell microstructure: preliminary study. Acta Universitatis Latviensis, 753 (Biology): 89-98.

Chafer, L. S. 1976. Systematic theology. Kregel Publications.

Daiga, J. 1976. Izrakumi Lipšu ciemā un kapulaukā. Zinātniskās atskaites sesijas materiali par arheologu, antropologu un etnografu 1975 gada pētrjumu rezultātiem. Rīgā,

Demarchi, B., Williams, M. G., Milner, N., Russell, N., Bailey, G., \& Penkman, K. 2011. Amino acid racemization dating of marine shells: a mound of possibilities. Quaternary International, 239(1), 114-124.

Demarchi, B., Hall, S., Roncal-Herrero, T., Freeman, C.L., Woolley, J., Crisp, M.K., Wilson, J., Fotakis, A., Fischer, R., Kessler, B.M., Rakownikow Jersie-Christensen, R., Olsen, J.V., Haile, J., Thomas, J., Marean, C.W., Parkington, J., Presslee, S., Lee-Thorp, J., Ditchfield, P., Hamilton, J.F., Ward, M.W., Wang, C.M., Shaw, M.D., Harrison, T., Domínguez-Rodrigo, M., MacPhee, R.D.E., Kwekason, A., Ecker, M., Kolska Horwitz, L., Chazan, M., Kröger, R., Thomas-Oates, J., Harding, J.H., Cappellini, E., Penkman, K., and Collins, M.J. (2016) Protein sequences bound to mineral surfaces persist into deep time. eLife [online] 5, e17092.

van Doorn, N. L., Hollund, H., \& Collins, M. J. 2011. A novel and non-destructive approach for ZooMS analysis: ammonium bicarbonate buffer extraction. Archaeological and Anthropological Sciences, 3(3), 281-289.

Eckstein, M. 1987. Ei. In: H. Bächtold-Stäubli \& E. Hoffmann-Krayer (eds.), Handwörterbuch des deutschen Aberglaubens. Walter de Gruyter. Berlin-New-York, pp 595-644.

Eisen, M., J. 1927. Eesti vana usk. Eesti Kirjanduse Seltsi Kirjastus Tartus.

Garmus, A. \& Jankauskas, R. 1993. Methods of person's identification from the skeleton in Lithuania. Medicina Legalis Baltica, 3-4, 5-23.

Jonuks, T. \& Kurisoo, T. 2013. To be or not to be... A Christian: some new perspectives on understanding the Christianisation of Estonia. Folklore. An electronic journal of folklore 55, pp 69 98.

Jonuks, T \& Rannamäe, E. in press. Animals and worldviews: a diachronic approach to tooth and bone pendants from the Mesolithic to the Medieval period in Estonia. In: Livarda, A; Madgwick, R (eds.) Bioarchaeology of Ritual and Religion. Oxbow.

Karlsson, O. \& Lilja, C. 2008. Eggshell structure, mode of development and growth rate in birds. Zoology, 111, 494-502

Keepax, C.A. 1981. Avian Eggshell from Archaeological Sites. Journal of Archaeological Science 8, 315-335.

Kolchin, В. А. (ed.) 1985. Древний Новгород: прикладное искусство и археология. 
Москва: Искусство.

Kustova, G.N., Burgina, E.B., Sadykov, V.A., Poryvaev, S.G. 1992. Vibrational Spectroscopic Investigation of Goethite Thermal Decomposition Products. Phyics and Chemistry of Minerals, 18, 379-382.

Lang, V. 2000. Keskusest ääremaaks. Viljelusmajandusliku asustuse kujunemine ja areng Vihasoo-Palmse piirkonnas Virumaal. Muinasaja teadus 7. Tallinn

Lavi, A. 1980. Über die Archäologischen Untersuchungen in Lahepera im Jahre 1978. ENSV Teaduste Akadeemia Toimetised. Ühiskonnateadused 4, Tallinn, pp 361 - 368.

Loorits, O. 1962. Zur christlichen Terminologie bei den Esten, Liven und Letten. Eesti Vaimulik Raamat. Uppsala, Arostryck

Lõhmus, M; Jonuks, T; Malve, M 2011. Archaeological salvage excavations at Kukruse: A Modern age road, cremation field and $12^{\text {th }}-13^{\text {th }}$ century inhumation cemetery. Preliminary results. Archaeological Fieldwork in Estonia 2010. Muinsuskaitseamet, Tallinn, pp 103 - 114.

Lougas, V. 1981. Kana ja muna Baltimaade arheoloogilises materjalis. Eesti ajaloo probleeme. Eesti NSV Teaduste Akadeemia Ajaloo Instituut, Tallinn, 96-103.

Maldre, L. 2000. Tõugu II kalme arheozooloogiline materjal. In: V. Lang (ed.), Keskusest ääremaaks. Viljelusmajandusliku asustuse kujunemine ja areng Vihasoo - Palmse piirkonnas Virumaal. Muinasaja Teadus 7. Tallinn, 409-422.

Maldre, L. 2003. Läänemaa kivikalmete arheozooloogiline aines. In: M. Mandel (ed.), Läänemaa 5. - 13. sajandi kalmed. Töid Ajaloo Alalt, 5. Eesti Ajaloomuuseum, Tallinn, 263-286.

Makarov, N. A. 2012. The Minino project: The investigation of a group of medieval sites in the Byeloozero region of northern Russia. In: M. A. Brisbane, N. A. Makarov \& E. N. Nosov (eds.) The Archaeology of medieval Novgorod in Context. Studies in centre/periphery relations. Oxbow Books, $40-57$.

Makatch, W. 1974. Die Eier der Vögel Europas. Eine Darstellung der Brutbiologie aller in Europa brütenden Vogelarten. Band 1. Leipzig, Radebeul: Neumann Verlag.

Makatch, W. 1976. Die Eier der Vögel Europas. Eine Darstellung der Brutbiologie aller in Europa brütenden Vogelarten. Band 2. Leipzig, Radebeul: Neumann Verlag.

Maltby, M. 2012. From Alces to Zander: A summary of the zooarchaeological evidence from Novgorod, Gorodishche and Minino. In: M. A. Brisbane, N. A. Makarov \& E. N. Nosov (eds.) The Archaeology of medieval Novgorod in Context. Studies in centre/periphery relations. Oxbow Books, $351-380$.

Marshall, L.J.R., Williams, J.R., Almond, M.J., Atkinson, S.D.M., Cook, S.R., Matthews, W., Mortimore, J.L. 2005. Analysis of ochres from Clearwell Caves: the role of particle size in determining colour. Spectrochimica Acta Part A, 61, 233-241.

Mägi, M. 2002. At the crossroads of space and time: Graves, changing society and ideology on Saaremaa (Ösel), 9th-13th centuries AD. CCC papers 6. Tartu: University of Tartu.

Napolskihh, V. V. 1989. The diving-bird myth in northern Eurasia. In: M. Hoppál \& J. Pentikäinen (eds.), Uralic Mythology and Folklore. Ethnologica Uralica. Budapest; Helsinki, 105113.

Ortner, D. J., Putschar, W. G. J. 1985 Identification of Pathological Conditions in Human Skeletal Remains. Smithsonian Institution Press.

Paxton, F. 2008. Birth and death. In: T. F. X. Noble \& J. M. H. Smith; R. A. Baranowski (eds.), The Cambridge History of Christianity. Vol 3, Early Medieval Christianities, c. 600 - 1100. Cambridge University Press, pp 383 - 398.

Penkman, K.E.H., Kaufman, D.S., Maddy, D., and Collins, M.J. 2008. Closed-System Behaviour of the Intra-Crystalline Fraction of Amino Acids in Mollusc Shells. Quaternary geochronology 3 (1-2), 2-25.

Presslee, S. 2015 Using ancient proteomics to identify the exploitation of bird eggs in archaeological contexts. York: University of York (unpublished thesis)

Rannamäe, E., Lõugas, L. in press. Animal exploitation in Karksi and Viljandi during the Late Prehistoric Times and the Middle Ages. In: Pluskowski A. G. (ed.) The Ecology of Crusading, 
Colonisation and Religious Conversion in the Medieval Eastern Baltic: Terra Sacra II. Leiden: Brepols.

Roberts, C., Manchester, K. 2012. The Archaeology of Disease. Third Edition. Cornell

Romanoff A. L., Romanoff A. J. 1949. The Avian Egg. New York: John Wiley \& Sons, Inc.; London: Chapman \& Hall, Ltd.

Samdal, M. 2000. Amuletter. Gjenstander med amulettkarakter $i$ vestnorske graver $i$ tidsrommet 350- 1000 eKr. Hovedfagsoppgave i arkeologi med vekt på Norden. Universitetet i Bergen.

Selart, A. 2009. Orthodox Churches in Medieval Livonia. In: A. V. Murray (ed.), The Clash of Cultures on the medieval Baltic frontier. Ashgate, pp $273-290$.

Shepard, J. 2008. Slav Christianities, 800-1100. In: T. F. X. Noble; J. M. H. Smith; R.A.Baranowski (eds.), The Cambridge History of Christianity. Volume 3. Early Medieval Christianities, c. 600-1100. Cambridge University Press, pp 130-155.

Sidell, E. J. 1993. A Methodology for the Identification of Archaeological Eggshells. University of Pennsylvania

Smith A.F. 2006. The Turkey: an American story. Illinois, USA: University of Illinois Press.

Sohlman, M. A. 2004. Gotländska minnen av vikingars färder i österled. In: Historiska Nyheter Ingår $i$ : Olga \& Ingegerd : vikingafurstinnor i öst. Stockholm: Historiska Museet pp.8-9.

Stenberger, M. 1977. Vorgeschichte Schwedens. Akademie-verlag, Berlin.

Stewart, J. R.M; Allen, R. B.; Jones, A. K. G.; Penkman, K. E. H.; Collins, M. J. 2013. ZooMS: making eggshell visible in the archaeological record. Journal of Archaeological Science 40(4): 1797-1804.

Strohalm, M., Kavan, D., Novák, P., Volný, M., Havlícek, V., 2010. mMass 3: a crossplatform software environment for precise analysis of mass spectrometric data. Anal. Chem. 82, 4648-4651.

Todd, T. W. 1921. Age changes in the pubic bone. III: The pubis of the white female. IV: The pubis of the female white-negro hybrid. American Journal of Physical Anthropology, 4, 1, 1-70.

Tvauri, A. 2001. Muinas Tartu: uurimus Tartu muinaslinnuse ja asula asustusloost. Muinasaja Teadus 10, Tartu, Tallinn

Ubelaker, D. H. 1989. Human Skeletal Remains. Excavation, Analysis, Interpretation. Manuals of Archaeology, 2. Second edition. Washington.

Urtāns, V. 1973. Aizkraukles arheologiskās ekspedīcijas 1972. gada darba rezultāti. Materiāli par arheologu, antropologu un etnogrāfu 1972 gada. Pètījumu rezultātiem. Izdevniecība "Zinātne" Rīgā, lk 66-70

Urtāns V. et al 1969 = Уртанс В. А.; Граудонис Я. Я.; Шноре Э. Д., Мугуревич Э. С.; Зарина А. 1969. Раскопки на территории строительства Рижской ГЭС. Археологические открытия 1966 года. Издательство "Наука" Москва, pp 279-284

Vahur, S., Knuutinen, U. \& Leito, I. 2009. ATR-FT-IR spectroscopy in the region of 500$230 \mathrm{~cm}^{-1}$ for identification of inorganic red pigments. Spectrochimica Acta Part A, 73, 764-771.

Vahur, S., Teearu, A. \& Leito, I. 2010. ATR-FT-IR spectroscopy in the region of 550$230 \mathrm{~cm}^{-1}$ for identification of inorganic pigments. Spectrochimica Acta Part A, 75, 1061-1072.

Vahur, S.; Teearu, A.; Peets, P.; Joosu, L.; Leito, I. 2016. ATR-FT-IR spectral collection of conservation materials in the extended region of 4000-80 $\mathrm{cm}^{-1}$. Anal Bioanal Chem, 2016, 408 (13), 3373-3379.

Valk, Ü. 2000. Ex ovo omnia: Where does the Balto-Finnic Cosmogony Originate? The Etiology of an Etiology. Oral Tradition 15/1, 145-158.

Zarina, A. 1973. Izrakumi Salaspils Laukskolā 1972 gadā, Zinātniskāa atskaites sesijas. Materiāli par arheologu, antropologu un etnogrāfu 1972 gada. Pētījumu rezultātiem. Izdevniecība "Zinātne" Rīgā, lk 76-80

Zariņa, A. 2006. Salaspils Laukskolas kapulauks 10.-13. gadsmits. LU Latvijas Vēstures Institūts. Latvijas Vēstures Institūta apgāds. Rīga. 
